\title{
小学校における運動部活動からスポーツ少年団への移行に伴う変化： 地域移行を経験した教員へのインタビュー調査から
}

\begin{abstract}
青柳 健隆
AOYAGI Kenryu : Changes associated with transition from school-based extracurricular sports activities to junior sports clubs in elementary school: Interviews with teachers experienced in regional transition. Japan J. Phys. Educ. Hlth. Sport Sci.
\end{abstract}

\begin{abstract}
In Japan, some elementary schools have an environment for extracurricular sports activities. However, due to the declining population and burdens on teachers, this arrangement has been difficult to sustain. As a result, some regions have transitioned from school-based extracurricular sports activities to community-based sports activities, and this trend is expected to eventually affect all regions. However, little has been clarified about the effect of regional transition of school-based extracurricular sports activities. The present study examined teachers' recognition of changes associated with the transition of elementary school-based extracurricular sports activities to community-based junior sports clubs. Face-to-face semi-structured interviews were conducted with 9 participants who had experienced regional transition as teachers. The interview topics included were: past sports implementation, pre-transition coaching status, coaching experience/thoughts/philosophy, present sports implementation status of children, and changes associated with regional transition. All interviews were transcribed verbatim. For qualitative analysis, the KJ method was used to conduct card making, grouping, type A modeling, and type B writing. As a result, 63 small categories were extracted and 5 large categories were created. These categories were as follows: 1) activity, 2) coaching and management, 3) teachers, 4) children, and 5) parents, each including both positive and negative changes. The "teachers" category was further classified into 4 subcategories: burden, educational opportunity, relationship with children, and relationship with parents. The relational model has shown that intense activity caused fatigue and lifestyle deterioration in children. Additionally, increasing the burden on parents resulted in a decrease of sports participation by children and a decrease of educational opportunities resulted in an increase of problems associated with pupil guidance and teacher burden. It is evident that teachers have recognized various changes related to activity, coaching and management, and also teachers, children and parents, and their inter-relationships. In particular, perceived negative changes due to regional transitions should be rectified. Simply transitioning school-based extracurricular sports activities to communitybased junior sports clubs will not be enough to resolve certain problems. It is important to follow management rules and allow cooperation among teachers, parents, and coaches to balance the sustainability of the sports environments available for children and their educational value. As the present case study targeted one region and evaluated only the perceptions of teachers, the suggestions offered are purely from a teacher's viewpoint and restricted to full transitioning from elementary school-based extracurricular sports activities to community-based junior sports clubs.
\end{abstract}

Key words : social physical education, extracurricular activity, qualitative study キーワード : 社会体育, 課外活動, 質的研究

関東学院大学経済学部

干 236-8501 神奈川県横浜市金沢区六浦東 1-50-1 連絡先 青柳健隆
College of Economics, Kanto Gakuin University

1-50-1, Mutsuurahigashi, Kanazawa-ku, Yokohama, Kanagawa 236-8501

Corresponding author aoyagi@kanto-gakuin.ac.jp 


\section{I 緒 言}

日本では, 多くの中高生が運動部活動に所属し ている. スポーツ庁 (2018a, p.9) によると, 中 学生の $72.5 \%$, 高校生の $54.5 \%$ が運動部活動に所 属しており, 部活動はスポーツを行う機会として 中心的な役割を果たしているといえる. しかし， 部活動を継続していくうえでの課題が持ち上がっ ている. そのひとつが顧問教員の過重負担であ る（中澤, 2017, pp.167-191; 内田, 2017). 特 に, 部活動非担当の教員や文化部担当の教員に比 べて, 運動部担当の顧問のワークライフバランス が悪いことが指摘されており（青柳，2019a）, 運 動部活動顧問教員の負担が大きい状況がうかがえ る.また，運動部活動の在り方に関する総合的な ガイドライン（スポーツ庁, 2018b, p.8）には「今 後, 少子化がさらに進むことを踏まえれば, ジュ ニア期におけるスポーツ環境の整備については, 長期的には, 従来の学校単位での活動から一定規 模の地域単位での活動も視野に入れた体制の構築 が求められる.」と記され, 少子化に伴う, 地域 を含めた持続可能な運動部活動の在り方について の検討も課題となっている. 部活動の地域移行は これまでも議論され, 実際に移行が試みられたこ ともあった。一部では成功した事例も存在し, 地 域移行（主に学校と総合型地域スポーツクラブと の連携・融合）のモデルケースとなっている（黒 須編, 2009 ; 永谷, 2015 ; 夏秋, 2003 ; 大竹・上 田, 2001 ; 高村・高橋, 2006). しかし全体的に 見れば，代替となる地域のスポーツ環境（受け 皿）の脆弱性や地域人材の不足，事故時における 保険制度の学校部活動の優越性などの理由(中澤, 2017, p.80；谷口, 2014 ; 内田, 2017, p.217）か ら地域移行は進展せず，依然として部活動を中心 に青少年スポーツは実施されている状況である.

中学校や高等学校に比べて実施されている自治 体や学校の割合は少ないが, 小学校においても部 活動を実施している地域がある. 先行研究では, 全国の $23.0 \%$ の市区町村では一部もしくはほとん どの小学校において運動部活動（教員が顧問を担
い，学校管理下で行われる課外活動）が行われて いることが示されている(青柳ほか, 2018).また, 小学校 $3 \cdot 4$ 年生の $13.6 \%, 5 \cdot 6$ 年生の $25.4 \%$ は 学校のクラブ活動・運動部活動に加入している というデータもあり（笹川スポーツ財団, 2017a, p.117), 京都市や成田市など小学校においても部 活動が行われている地域では, ガイドラインを作 成して組織的に部活動を運営している（京都市立 小学校運動部活動の在り方に関する検討委員会, 2017 ; 成田市教育委員会, 2018). 小学校におけ る部活動の指導・運営は, 教員としての業務や学 校運営に影響することが指摘されており（熊本市 教育委員会, 2017), 小学校においても中学校や 高等学校のように教員の負担が存在していること が推察される. また, 小学校では学校スポーツに 対する少子化の影響も顕著である. 2019 年版の 文部科学統計要覧をもとに学校当たりの平均児童 生徒数を計算すると, 高等学校では 661 人, 中学 校では 317 人, 小学校では 323 人となる（文部科 学省, 2019). 小学校低学年の部活動加入率は低 いこと（笹川スポーツ財団，2017a，p.117）ま ま た原則的に入部を 4 年生以上に限定する規則の存 在（熊本市教育委員会，2017）を踏まえて 4 年生 以上で再計算すると, 小学校では 164 人という数 值が算出される.これより, 小学校では中学校や 高等学校以上にチームが組みにくい状況が予想さ れる. 以上のように, 中学校や高等学校と同様に, 小学校でも教員の過重負担や少子化の影響などの 課題がある中, 日本スポーツ協会総合企画委員会 （2018）は，「子どものスポーツ権」の保障を第一 義として, スポーツ少年団や総合型地域スポーツ クラブを含めた地域スポーツクラブを土台とした 地域のスポーツ環境の整備の必要性を訴えてい る.

少子化に伴うチーム編成の困難さやニーズの多 様化, 指導者教員不足などの課題を背景に（大 杉・今田, 2016), 小学校では部活動の廃止を決 めた自治体もある. 2019 年 3 月までで熊本県の 多くの自治体（熊本市は部活動の縮小存続の方 針）が部活動を廃止し（熊本県阿蘇市，2018；熊 本市教育委員会, 2017), 愛知県の名古屋市や豊 
橋市も 2021 年 3 月までで廃止を決定した（東愛 知新聞， 2019 年 7 月 10 日; 名古屋市教育委員 会, online). 青柳ほか（2018）の調査でも 2006 年から 2016 年までの間に部活動が廃止された市 区町村が 112 地域（全市区町村の 6.4\%）あるこ とが報告されている．現在は部活動を設置してい る小学校においても, 教員の負担や少子化といっ た共通の課題を考慮すると, 今後部活動の廃止を 検討する可能性もあるだろう。ただし部活動の廃 止については, 日本スポーツ協会総合企画委員会 （2018）の「子どものスポーツ権」の保障の視点, 保護者や地域住民の多くが部活動廃止後の子ども のスポーツ環境の必要性を認識していること（朝 日新聞, 2018 年 9 月 23 日; 熊本県阿蘇市, 2018), 実際に部活動を廃止する各自治体において地域移 行の方策を検討していること（天草市, 2016 ; 益 城町，2018）から，単に部活動の廃止というより はスポーツ環境の学校から地域への移行と捉えて 検討していく必要がある.

小学校部活動の地域移行に関する研究はほとん ど見られず，例えば熊本県では 1970 年代, 部活 動中の事故 (損害賠償の判例), 教員の手当や勤 務時間の問題, 多額の経費など教育上望ましくな い結果の招来などを背景に部活動の地域移行が進 められたが, 部活動指導手当の充実や保険に関連 する法改正，部活動が教育活動として位置づけら れたことに伴って, 再び部活動に戻ったという 事例が報告されている程度である（中澤，2014， pp.119-120; 大杉・今田, 2016). 中学校や高等 学校の部活動に関しては, 前述したように学校部 活動と地域スポーツクラブの連携の成功事例とし て数件が報告されている. 大竹・上田（2001）は 学校運動部活動と地域スポーツクラブの融合につ いて，その意義や可能性を考察し，学校施設を拠 点とした地域クラブ運営の先進的事例として杉並 区の「向陽スポーツ文化クラブ」と愛知県半田市 の「成岩スポーツクラブ」を挙げている．向陽ス ポーツ文化クラブは近隣中学校に部活動がない種 目や部活動に入らない生徒の受け典としても機能 していた。成岩スポーツクラブは成岩中学校を中 心としているが近隣の小学校の施設も有効に活用
している. 両クラブの共通点として, 学校関係者 が社会体育の重要性を認め, 地域社会へ積極的な アプローチを行ったことが指摘されている. 夏秋 （2003）も成岩スポーツクラブを取り上げ，クラ ブの形成過程と主に小中学校 (中学校部活動) と の関わりに言及している. クラブは「地域の子ど もは地域の大人が育てる」という考えのもとで運 営され, 独立財源基盤を持ち, 中学校区人口の約 $11 \%$ \%登録するほどになった。しかし, クラブの 設立と学校との連携推進には, 子どもたちの多様 性が増すことによる学校教育との不調和や, 地域 移行に対する抵抗感 (負担感), 設備や指導・運 営者の必要性など, 問題も複数あることが示され ている. 高村・高橋（2006）は地域サッカークラ ブ「ソレステレージャ奈良 2002」の設立背景や 運営状況, 近隣の小中学校との関わりを示した. 地域移行のメリットとして, 子どもが自分の考え にあったクラブを選択できるようになった点と, クラブ出身者が社会人になったときに指導者とし てクラブに戻ってこられる点を挙げている乼1). クラブが抱える問題点としては，ハード面の制約 によって練習開始時間が遅くなること（下校時間 後, 小学生は 15 時半から, 中学生は 17 時からに 限定される), 指導者不足や指導者に十分な報酬 を渡せていないことが挙げられた。また, 地域移 行の成功要因としては, 教員の積極的関与, 人間 教育を根底とした活動方針, 責任の明確化（保険 加入）などが考察されていた。永谷（2015）は主 に中学校部活動と総合型地域スポーツクラブの連 携について, 都市部と地方都市の連携状況の比較 を行い, 連携推進には学校や教育行政が移行に前 向きであること, 過疎化や人口減少などの差し迫 った事情があること, 行政のフットワークの軽さ が関連していることを指摘した。

一方で, 失敗事例に注目した研究もある。中澤 （2008）は保護者の関わりに注目し，公立中学校 サッカー部における一連の部活動改革の結果, 地 域社会に移行されずに学校に留まり続けた部活動 の事例を報告した．本論では前顧問の異動から消 極的な顧問への転換, 地域クラブ化（休日の指導・ 運営や非公式の対外試合活動を保護者の責任で行 
うこと）の検討，事故補償問題の懸念，そして数 か月の施行を経て，生徒のけがを契機とした学校 部活動への回帰というプロセスと保護者の心情お よび関わりが詳細に記述されている。まとめとし て, 部活動改革に影響するのは学校がイニシアチ ブを発揮したかどうかだけではなく，イニシアチ ブを発揮できる保護者との良好な関係という文脈 が存在しているのではないかと問題提起した。谷 口（2014）は，一度関係を構築しながらも負傷事 故（訴訟）を契機に関係を消失するに至った公立 中学校と総合型クラブを事例とし, 学校に存在す る「変革動向からの回避志向性」, すなわち現状 維持を望む教員文化を見出した。また，別稿では 総合型クラブの育成を担当する立場にあった指導 主事への調査から，中高部活動と総合型クラブと の連携が進まない理由として，現状維持を指向し ようとする「改革と踏襲をめぐる躊躇いの常態化」 と集約される行政文化および学校文化を指摘して いる（谷口，2018）。そのほか，中学校の部活動 指導において重視されていることと地域スポーツ クラブで求められている「スポーツの主人公にふ さわしい能力」には共通性があるとする研究（依 田ほか，1997）や，全国の総合型地域スポーツク ラブのクラブ数や種目数, 指導者数などを考慮す ると部活動の完全移行の受け㿼としては不十分で あるとする研究（石井ほか，2016）などが行われ ている.

先行研究を概観すると，なぜ部活動の地域移行 がうまくいかないか，またはどうすればうまくい きそうかという文化的・政策的な，特に運営面へ の示唆を得ることができる。しかし，地域移行に よって何が起きるのかという現象面は主題として 扱われていない，子どもにとって有益なスポーッ 環境整備を検討していくためには，部活動の地域 移行が子どもや学校教育にどのような影響や変化 をもたらすのかを理解することが重要である。そ こで本研究では, 小学校において部活動を廃止し, 地域移行を実行した自治体 A を事例とし，地域 移行を経験した小学校教員の認識に着目した。部 活動の地域移行によってどのような部分に変化が 生じるのかも仮説立てられていない現状におい
て，移行の現場に居合わせ，教育者という視点で 変化を目の当たりにした教員の認識は，地域移行 によって子どもや学校教育にどのような影響や変 化があったのかを探索的に理解するために有益で あると考える．自治体 A ではスポーツ少年団が 部活動の移行先としての役割を担った．スポーツ 少年団（特に子どもの実際の活動単位である単位 スポーツ少年団）とは，団員である子どもを中心 に，保護者・地域住民が指導者やサポーター（育 成母集団）として指導・運営が行われている活動 である（日本スポーツ協会日本スポーツ少年団, 2018，p.16）。2019 年度は全国で 30,565 団あり， 649,289 名が団員として登録されている全国的に 見ても規模の大きいスポーツ組織である（日本ス ポーツ協会，2019). 団員の約 9 割は小学生であ り（笹川スポーツ財団，2017b，p.100），小学生 を中心とした活動であると理解できる。本研究で は, 自治体 A の小学校において, 部活動からス ポーツ少年団に移行したことによってどのような 変化が生じたのかに関する教員の認識を整理する ことを目的とした。

\section{II 方 法}

\section{1. 対象地域および対象者}

対象地域である自治体 A は人口 5 万一 10 万人 程度の地方都市であった。自治体 A では伝統的 に多くの小学校で部活動が実施されてきたが，少 子化（学校の小規模化）に伴う種目の選択肢の減 少，専門的に指導できる教員の不足，教員の人事 異動に伴う指導・運営の一貫性のなさなどの状況 に対応するため, 2011 年度から 2014 年度にかけ て，段階的に小学校の部活動をスポーツ少年団へ と移行した。2 2011 年度から 2013 年度までは移行 検討期と位置付けられ，2014 年度が完了期とさ れた。この期間内に打ける移行のタイミングや教 員の関わりの度合いは学校によって異なってい た.

対象者は, 部活動の地域移行前後を小学校教員 として経験した者 9 名であった。内訳は男性が 5 名，女性が 4 名であり，30 代，40 代，50 代，60 
代が含まれた. 全員が部活動の担当経験を有して おり，3名が管理職経験者であった。

\section{2. 調查手続き}

全ての対象者に対し, 1 対 1 の半構造化インタ ビューを実施した。インタビューはインタビュー ガイドに基づきすべて著者が行い，対象者の同意 のもと IC レコーダーで録音した．インタビュー ガイドの作成に当たっては，本調査実施前に対象 地域の小学校教員に対して予備的なインタビュー を行い，本研究の目的に沿って質問項目を決定し た．移行直後から変化が顕在化し定着するまでの 期間を考慮し, 調査は完全移行から 4 年が経過し た 2018 年 9 月に実施した。本研究では条件に該 当する対象者を選定し，性や年代の偏りを少なく するため，縁故法を用いた合目的的サンプリング を行った，質問内容として，対象者の背景を理解 するために，部活動をしていた頃の実施状況・指 導状況・指導経験，部活動に対する考えや指導理 念，現在の児童のスポーツ実施状況を聞き取っ た. また，本研究の主軸となる移行に伴う変化に 関しては，教員の視点から見た教員や子ども，学 校にとってのプラスの変化, マイナスの変化など, 切り口を変えながら回答が出尽くすまでオープン エンドの対話を続けた。

インタビューに先立ち, 対象者に対して本研究 の目的および方法, 個人情報の保護, 参加は自由 意志であることなどを説明し，文書による同意を 得た。インタビューを実施した場所は対象者の勤 務先の会議室など，プライバシーの保たれる空間 であった．なお，本研究は関東学院大学の「人に 関する研究倫理審査委員会」の承認を得て実施さ れた（承認番号：H2018-1-3）。

\section{3. 分析方法}

録音したインタビュー音声はすべて逐語化し， KJ 法（川喜田，1970）を用いて分析した．KJ 法 は発想法とも言われ，資料やインタビューなどの 基礎データからまとまりやつながりを発見してい く質的研究手法である. 仮説形成的（アブダクテ ィブ）なアプローチであり，緒言に示したように
「部活動の地域移行によってどのような部分に変 化が生じるのかも仮説立てられていない」本研究 のようなテーマに適した分析手法である. 手順を 大別すると(1)紙切れづくり，(2)グループ編成，(3) $\mathrm{A}$ 型図解, (4) $\mathrm{B}$ 型文章化の 4 つの分析局面に分 けられる. (1)紙切れづくりでは, 集めたデータか らそのデータのエッセンスが含まれたメモ（紙切 れ）を作成する. (2)グループ編成では，作られた すべての紙切れを机上等に広げ，全体を眺めなが ら親近感を感じる紙切れ同士を小分けから大分け へという順序で集めてゆく. 集まった紙切れには それらが表す意味を代表する見出しをつける（表 札づくり). (3) A 型図解では, 表札をつけた紙切 れの束を机上等に空間的に配置し，動かしながら 意味が首尾一貫した落ち着きの良い構図を探す。

(4) $\mathrm{B}$ 型文章化では，A 型図解を文章にしていき, 文章化の過程で行き詰まりやより良いアイデアが ないかを確認する，本研究では，はじめに逐語録 を精読しながら移行に伴う変化であると判断でき る部分を同定し，ひとつの意味内容を示す紙切れ を作成した（1)紙切れづくり），その際，複数の 変化を含む文章については紙切れを複製した。次 に机上に紙切れを広げ，全体を眺めながら類似す る紙切れをまとめてラベルを付け，小カテゴリを 生成した。ささらに，小カテゴリの類似性や差異か ら, 中カテゴリ, 大カテゴリ, 変化の方向性（プ ラス，中立，マイナス）をグルーピングした（2) グループ編成). 変化の方向性については，イン タビューが教員の立場から「教員自身や子ども, 学校にとってプラスかマイナスか」という視点で 語られたものであることに基づき，回答者の発言 内容やニュアンスから，それがプラスのものか, マイナスのものか，あるいは中立的なものかを分 析者が判断した。「マイナス面は○○です」や「○ ○できるようになった」などのような直接・間接 的に変化の方向性を示す表現を含まず，インタビ ユー中の発言自体から変化の方向性が読み取れな いものについては,インタビューの前後の文脈(例 えば，質問者の「プラスの変化を先に聞きたいの ですが」などの質問に続く文脈で発話されている 場合など）から，プラスマイナスいずれの変化に 
ついての語りなのかを判断した。それでも変化の 方向性が判別できなかった場合や，回答者自身が 「プラスなのかマイナスか, どちらにも捉えられ るのですが」などと前置きしている場合について は中立と評価した。 その後，インタビュー中に相 互関係や影響関係を示唆する発言のあったカテゴ リについて，関係性を可視化するためのモデル化 を行った (3) A 型図解)。最後に，グループ編成 および $\mathrm{A}$ 型図解の結果をもとに，言語化を行っ た（4) B 型文章化）.

\section{III 結 果}

グループ編成の結果を表 1 に示す．なお，本文 中の結果および考察のセクションでは，大カテゴ リを【 】,中カテゴリを下線,小カテゴリを「」 にて表記する．63 の小カテゴリは【活動】【指導・ 運営】，【教員】，【子ども】，【保護者】に関する 5 つの大カテゴリに大別され，【教員】に関しての み負担, 教育の機会, 子どもとの関係, 保護者と の関係とさらに 4つの中カテゴリに区分された.

【活動】に関しては,「練習時間が短くなった」,「ス ポーツの掛け持ちがしやすくなった」というプラ スの変化，「遠出するようになった」，「通年にな った」などの中立の変化，「開始・終了時間が遅 くなった」「練習量が増えた」などのマイナスの 変化が見出された。【指導・運営】に関しては,「指 導者が変わりにくくなった（地域の指導者の場 合)」，「専門的指導を受ける機会が広がった」と いうプラスの変化，「練習日数・時間が守られな い」，「教育的配慮が不足している」などのマイナ スの変化がまとめられた.【教員】の負担に関し ては，「プライベートの時間が増えた」などのプ ラスの変化，「帰宅時間は変わらない」という中 立の変化（変化していないという変化に関わる小 カテゴリ),「部活動以外の業務が増えた」などの マイナスの変化が認められた．教育の機会につい ては，「部活動に入っていない子どものケアが充 実した」などのプラスの変化と，「部活動の持つ 教育効果が得られなくなった」などのマイナスの 変化が見受けられた。 子どもとの関係については
「信頼関係が築きづらい」など，保護者との関係 についても「保護者と知り合う機会が減つた」な どと, マイナスの変化のみが挙げられた.【子ど も】に関しては,「子どもが自分の時間を持てる」, 「技能が向上した」というプラスの変化と，「スポ ーツをする子どもが減った」,「生活習慣が悪化し た」などのマイナスの変化が抽出された．最後に 【保護者】に関しては，「保護者の子どもへの関わ りが増えた」というプラスの変化の一方で，「保 護者の時間的・身体的負担が増えた」，「保護者同 士のトラブルが増えた」などのマイナスの変化が 生じていた.

続いて, A 型図解の結果を図 1 に示し（分析方 法でも示したように，インタビューにおいて因果 関係を示唆する発言のなかった 17 の小カテゴリ は表記していない)，以下に B 型文章化の結果を 記述する.【指導・運営】の「練習日数・時間が 守られない」こと，および【活動】の「遠出する ようになった」ことや「参加大会が増えた」こと などの変化により，【子ども】の「生活習慣が悪 化した」り,「疲れている」子どもが見受けられる. また，「遠出するようになった」ことや「参加大 会が増えた」ことなどの【活動】の変化は，その 大変さから「スポーツをする子どもが減った」こ とにつながっている，同時に「保護者の時間的 . 身体的負担が増えた」ことや「保護者の経済的負 担が増えた」ことにより，「加入させない・させ られない」保護者が現れ，結果として「スポーツ をする子どもが減った」。

他方，【指導・運営】に颃いて「教育的配慮 が不足している」ことや「マナー指導が不足し ている」ことで,【子ども】の「生徒指導上の問 題が増えた」り，「礼儀・挨拶・マナーが悪化 した」りした.【子ども】のこの変化には【教 員】の教育の機会の減少や子どもとの関係の希 薄化も影響している（教育の機会と子どもとの 関係は双方向的に密接な関係がある). 生徒指導 上の問題増加は【教員】の「生徒指導上の対応 が増えた」ことに影響している．それに加えて， 「部活動以外の業務が増えた」という夐担の増加, 「部活動に入っていない子どものケアが充実した」 
表 1 部活動からスポーツ少年団への移行に伴う変化

\begin{tabular}{|c|c|c|c|}
\hline 大カテゴリ & 中カテゴリ & 変化の方向性 & 小カテゴリ \\
\hline \multirow[t]{12}{*}{ 活動 } & & プラス & 練習時間が短くなった \\
\hline & & & スポーツの掛け持ちがしやすくなった \\
\hline & & 中立 & 遠出するようになった \\
\hline & & & 通年になった \\
\hline & & & $\begin{array}{l}\text { 加入年齢が下がった } \\
\end{array}$ \\
\hline & & & 参加大会が増えた \\
\hline & & & $\begin{array}{l}\text { 上下 (先輩後輩) 関係が弱まった } \\
\end{array}$ \\
\hline & & & 活動時間が二極化した \\
\hline & & マイナス & 開始・終了時間が遅くなった \\
\hline & & & 練習量が増えた \\
\hline & & & 土日の活動が増えた \\
\hline & & & 学校の施設が使えなくなった \\
\hline \multirow[t]{12}{*}{ 指導 • 運営 } & & プラス & 指導者が変わりにくくなった（地域の指導者の場合） \\
\hline & & & 専門的指導を受ける機会が広がった \\
\hline & & マイナス & $\begin{array}{l}\text { 指導者が変わりやすくなった（保護者の場合） } \\
\end{array}$ \\
\hline & & & スポーツ少年団の規約が守られない \\
\hline & & & 練習日数・時間が守られない \\
\hline & & & 教育的配慮が不足している \\
\hline & & & 学校のことがないがしろになる \\
\hline & & & $\begin{array}{l}\text { 結果を重視しがち } \\
\end{array}$ \\
\hline & & & 他人の子どもを叱れない \\
\hline & & & 子どもを公平に扱えない \\
\hline & & & マナー指導が不足している \\
\hline & & & 言葉遣いが荒い \\
\hline \multirow[t]{22}{*}{ 教員 } & 負担 & プラス & プライベートの時間が増えた \\
\hline & & & 部活動に関わる事務作業が減った \\
\hline & & & 部活動に関わるストレスが減った \\
\hline & & & 身体的負担が減った \\
\hline & & 中立 & 帰宅時間は変わらない \\
\hline & & マイナス & 部活動以外の業務が増えた \\
\hline & & & 生徒指導上の対応が増えた \\
\hline & 教育の機会 & プラス & 部活動に入っていない子どものケアが充実した \\
\hline & & & 部活動以外の業務ができるようになった \\
\hline & & マイナス & 部活動の持つ教育効果が得られなくなった \\
\hline & & & 生徒指導の機能が落ちた \\
\hline & & & 学校の教育効果が減った \\
\hline & & & 相乗的・補完的な指導の機会が減つた \\
\hline & 子どもとの関係 & マイナス & 信頼関係が築きづらい \\
\hline & & & スポーツ少年団でのトラブルとの距離感が難しい \\
\hline & & & 子どもとの関わりが薄くなった \\
\hline & & & 他学年の子どもと関わらなくなった \\
\hline & 保護者との関係 & マイナス & 保護者と知り合う機会が減った \\
\hline & & & 保護者と共に喜び合う機会が減った \\
\hline & & & 保護者との関係が希薄化した \\
\hline & & & 教員や学校に対する感謝や信頼感が減った \\
\hline & & & 教員の意図や思いが伝わりづらい \\
\hline
\end{tabular}


表 1 続き

\begin{tabular}{|c|c|c|}
\hline \multirow[t]{10}{*}{ 子ども } & プラス & $\begin{array}{l}\text { 子どもが自分の時間を持てる } \\
\text { 技能が向上した }\end{array}$ \\
\hline & マイナス & スポーツをする子どもが減った \\
\hline & & 技能が低下した \\
\hline & & 子ども同士のスポーツに関する会話が減った \\
\hline & & 中学校で部活動を退部する子どもが増えた \\
\hline & & 子ども同士のトラブルが増えた \\
\hline & & 生活習慣が悪化した \\
\hline & & 疲れている \\
\hline & & 生徒指導上の問題が増えた \\
\hline & & 礼儀・挨拶・マナーが悪化した \\
\hline \multirow[t]{6}{*}{$\begin{array}{l}\text { 保護者 } \\
\end{array}$} & プラス & 保護者の子どもへの関わりが増えた \\
\hline & マイナス & 保護者の時間的・身体的負担が増えた \\
\hline & & 保護者の経済的負担が増えた \\
\hline & & 保護者同士のトラブルが増えた \\
\hline & & 加入させない・させられない \\
\hline & & 学校へのクレームが増えた \\
\hline
\end{tabular}

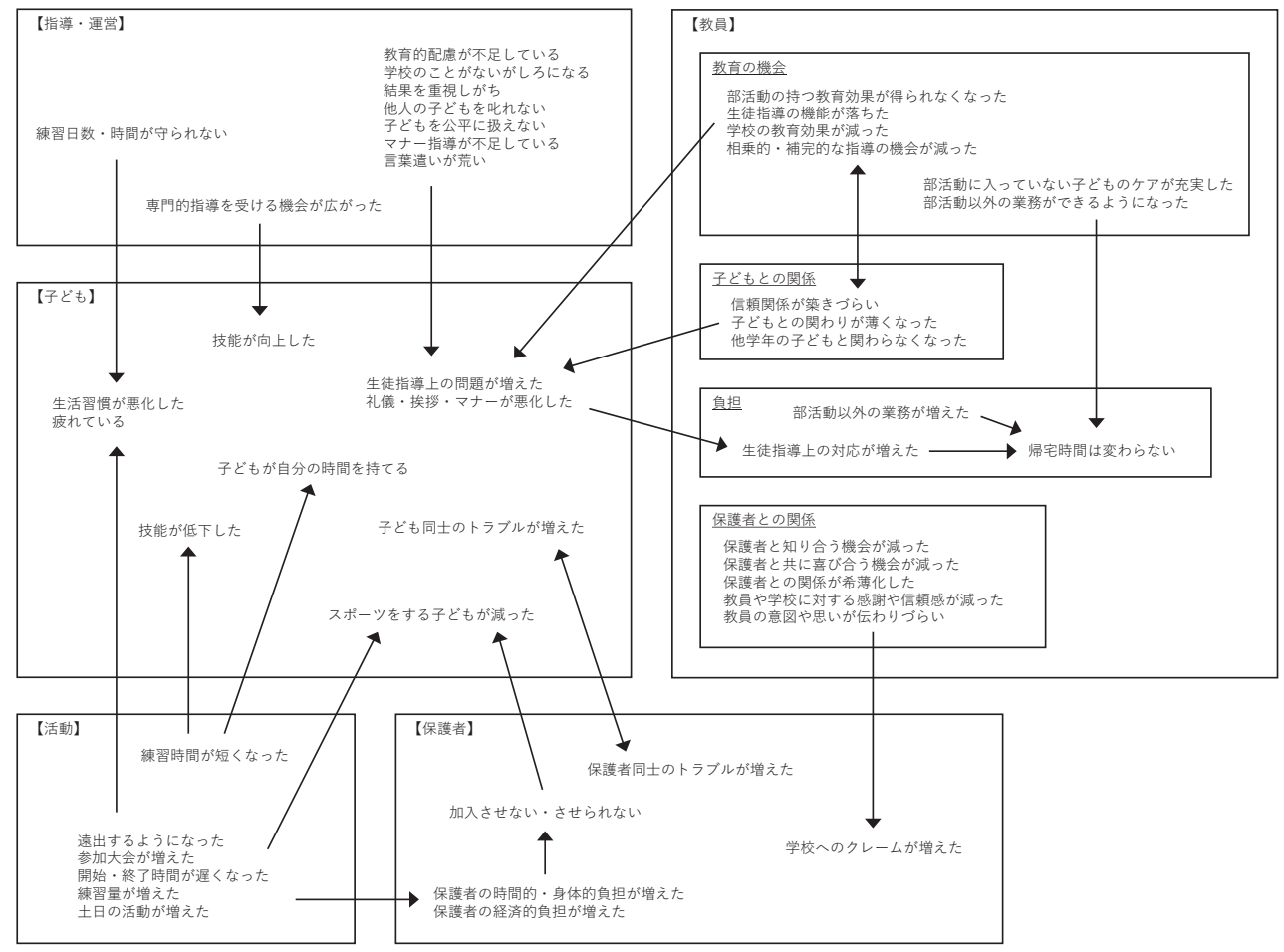

図 1 部活動からスポーツ少年団への移行に伴う変化の関係性

ことや「部活動以外の業務ができるようになった」 という教育の機会の増加によって勤務日の「帰宅 時間は変わらない」状況も生まれている。

【教員】の保護者との関係について，「保護者と
知り合う機会が減った」り,「教員や学校に対す る感謝や信頼感が減った」ことなどから,【保護者】 の「学校へのクレームが増えた」という実態も見 出された.また,「保護者同士のトラブルが増えた」 
ことは「子ども同士のトラブルが増えた」ことと 両方向性の関係が認められた。そのほか, 【指導・ 運営】において「専門的指導を受ける機会が広が った」ことは【子ども】の「技能が向上した」こ とに影響し、【活動】で「練習時間が短くなった」 ことは【子ども】の「技能が低下した」ことや「子 どもが自分の時間を持てる」ととに影響していた.

\section{IV 考 察}

本研究では, 小学校において部活動からスポー ツ少年団に移行したことによってどのような変化 が生じたのかに関する教員の認識を整理すること を目的に, 部活動の地域移行前後を小学校教員と して経験した者 9 名に対してインタビュー調査を 実施した. 分析の結果, 【活動】、指導・運営】、教 員】,【子ども】,【保護者】に関するプラスの変化 やマイナスの変化が見出された. また, それぞれ の変化がほかの変化に影響するという関係性もモ デル化された.

地域移行の背景のひとつに教員の過重負担があ つた. 本研究では教員の負担に関するプラスの変 化として, プライベートの時間が増えたこと, 部 活動に関わる事務的・ 心理的・身体的な負担が減 ったことが報告され, ねらい通り負担軽減が認識 されていた. しかし, 子どもの生徒指導上の問題 増加に伴って生徒指導上の対応が増えたり, 部活 動のかわりにほかの業務が増えたりする側面もあ つた，総合すると，部活動を担当しなくなったこ とによる直接的な負担軽減は実現したが, 間接的 な教育負担の増大や他業務の増加によって教員の 負担軽減への影響は限定的であると考えられる. OECD 国際教員指導環境調查（TALIS）2018 報告 書（国立教育政策研究所編，2019，p.13）による と, 日本の小学校教員の仕事時間は 54.4 時間と, 比較した 15 か国中最長であり, 日本を除く 14 か 国の平均である 39.2 時間に比べて非常に長いこ とがわかる.この統計における日本の「課外活動 の指導（例：放課後のスポーツ活動や文化活動)」 は 0.6 時間であり, 他国平均の 1.2 時間と比較し ても短いほうである注2) ことを踏まえると, 教員
の負担軽減を実現するためには, 部活動以外の業 務負担も含めた業務量の管理や効率化が不可欠で ある.

教員の直接的な部活動負担が減少した一方で, 指導・運営を担うことになった保護者の時間的・ 身体的・経済的負担は増加したと認識されてい た. それによって子どもをスポーツ少年団に加入 させない・させられない保護者もおり, 結果とし てスポーツをする子どもが部活動として運営され ていた時よりも減少していた，この関係性は, 保 護者の負担感が大きいことが団員を増やしにく い要因となっているという鳥取県の事例（松本, 2019）とも符合する. それまで指導・運営してい た者（教員）の負担を他者（保護者）に移行する のであるから, 負担のトレードオフ関係は当然生 じることである. スポーツ少年団組織と活動の在 り方を示したガイドブック（日本スポーツ協会日 本スポーツ少年団, 2018）にも「保護者の中には, 仕事の関係で休日の活動に参加できない方もいま す.そのような方への配慮を欠かさない方法で, お互いに協力し合っていきましょう.」と記載が あるように, 保護者の事情によって子どものやり たいスポーツができない状況は,「子どものスポ 一ツ権」を保障する観点からも改善が求められる 点であろう。

地域移行のもうひとつの大きな背景は少子化を 見据えたスポーツ環境の持続可能性, 具体的に は, 学校単位でチーム編成することの困難さ, 種 目の選択肢の少なさ, 子どもや保護者のニーズの 多様化, 専門的に指導できる教員の不足などであ った. 本事例の結果では活動に関するプラス面と して, スポーツの掛け持ちがしやすくなったこと が挙げられ, 指導・運営に関するプラス面では（地 域指導者の場合には）指導者が変わりにくくなっ たことや専門的指導を受ける機会が広がったこと が示された.これらのことから, スポーツ種目の 選択肢の広がりと指導の継続性や専門性の向上が もたらされ, 課題解決に寄与していたと考えられ る. 一方で, 学校の施設が使えなくなったことや （指導者が保護者の場合に）指導者が変わりやす くなったこと, 保護者が加入させなかったり加入 
させられなかったりする場合もあり，スポーツを する子どもが減ったことなど，持続可能性が低下 したと考えられる認識も見受けられた．単に部活 動をスポーツ少年団へ移行するという取り組みだ けでは必ずしも持続可能性が向上するとはいえな いため，学校の施設利用方法，指導者の継続性向 上，子どもが加入しやすいスポーツ環境づくりな ぞ，運営上の工夫をあわせて行う必要がある．例 えば，保護者や教員と比べて継続性が高いと考え られる地域指導者を確保するためには，部活動の 地域移行を進める熊本県の自治体のような, 指導 者や支援者を募集・登録し，スポーツ少年団とマ ッチングするなどの工夫（益城町，2018; 西原村, online）も参考になるだろう.

上記に関連して，「指導者が変わりにくくなつ た（地域の指導者の場合）」，「指導者が変わりや すくなった（保護者の場合）」と結果の一部には スポーツ少年団の事情によって方向性の一致しな い変化が認識されていた。活動や指導・運営の内 容についても，「練習時間が短くなった」という 意見がある一方で，「練習量が増えた」，「土日の 活動が増えた」「練習日数・時間が守られない」 など，練習量が増加したという意見が挙げられ， 「活動時間が二極化した」と感じている対象者も いた．部活動のスポーツ少年団への移行による変 化は移行それ自体によって必ずしも生じるわけで はなく, 活動や指導・運営上の工夫によってもた らすことのできる，または防ぐことのできるもの があると考えられる. スポーツ少年団の規約など， 各自治体で定められたルールを守ってスポーツ少 年団を運営していくことで, 望ましくない変化を 抑制することができるだろう。

他方で, 教育的な視点から見ると教育の機会に 関する変化は看過できない。「部活動に入ってい ない子どものケアが充実した」,「部活動以外の業 務ができるようになった」というプラスの変化も 認識されているが，「部活動の持つ教育効果が得 られなくなった」,「生徒指導の機能が落ちた」,「学 校の教育効果が減った」,「相乗的・補完的な指導 の機会が減った」という変化はいずれも教育機関 である学校においては重大な問題である。また,
部活動という場で子どもと接する機会がなくな り，子どもとの関わりが薄くなったり，信頼関係 が築きづらくなったりすることも，教育上望まし くない変化といえる．保護者との関係の希薄化も 教員の意図や思いが伝わりづらかったり，保護者 から学校へのクレームが増えることにつながった りするなど，円滑な教育活動を実施していく上で の問題を有している. 指導・運営面においてスポ ーツ少年団での教育的配慮が不足していることや 学校のことがないがしろになってしまう場合があ ることもあわせて考えると，地域移行によってス ポーツを学校から切り離しただけではなく, 教育 機能の一部を切り離したと捉えることもできる. 移行前までは学校教育の一環として行われていた 活動がなくなる（教育の専門家である教員の管理 下から離れる）のであるから，その活動が有して いた教育機能が失われるのはいわば当然の帰結で あろう．移行前と同等の教育効果を前提とするの であれば，どのようにして部活動ではない部分で 教育の機会を確保していくか，子どもや保護者と の信頼関係を築いていくかが検討課題となる。ま たは，教員がスポーツ少年団に関わり，連携を持 つ方法もある．スポーツ少年団への小学生の登録 率が高いある自治体では，スポーツ少年団と学校 との連携が取れており，スポーツ少年団との渉外 担当の教員がいたり，校庭や体育館の利用調整な どの支援をしている（朝日新聞，2020 年 4 月 23 日). 学校や教員が関わらない完全な地域移行で はなく，学校の資源を活用し，教員と保護者や地 域指導者が協㗢することが，持続可能かつ教育的 な意義のある子どものスポーツ環境を整備してい くことにつながると考えられる，もしくは，教員 の負担の大きさも踏まえてこれまでが過剩であっ たという立場に立つならば，どの程度の教育投資 をし，どの程度の教育成果を期待するのかを考え なくてはならない。青柳（2019b,pp.144-145）は, 教育の負担，教育の質，財政の 3 つのバランスの 中でどこに資源を投下するかを考えることで，限 られた教育資源の中で効果を最大化する方策を検 討することの重要性を指摘している．部活動の地 域移行が教員の負担，教育の質，財政にとって直 
接的・間接的に，または中長期的にどのような変 化をもたらすかは，今後定量的な指標も用いて検 証していく必要がある，そもそも部活動を実施し ていない自治体もあるため, 実施している自治体 としていない自治体の比較なども有益な示唆を与 えうる.

\section{V 結 論}

小学校における部活動からスポーツ少年団への 移行によって, 本事例では活動や指導・運営の内 容, 教員, 子ども, 保護者それぞれに関する変化 を教員が認識していることが確認された．教員と 子ども, 教員と保護者の関係性においても変化が 認識されていた。特に移行により悪化したと認識 されていた点（マイナスの変化）については, 改 善方法を検討していく必要がある. 単に部活動を スポーツ少年団へ移行するだけでは必ずしも期待 する効果（教員の負担軽減や持続可能性の向上な ど）が望めるわけではないと考えられるため, 規 約等のルールを順守し, 運営上の工夫をあわせて 行う必要がある. また, 子どものスポーツ環境の 持続可能性と教育的価值を両立させていくために は，教員，保護者，地域指導者が協働して指導・ 運営していくことが重要である.

最後に, 本研究の限界点と今後の展望について まとめる. 本研究はひとつの自治体の限られた対 象者を事例とした研究であるため, ほかの自治体 や今回インタビューした対象者が認識していない スポーツ少年団に対して，そのまま一般化するこ とができない. 中学校や高等学校, 単純な部活動 廃止やスポーツ少年団以外（総合型地域スポーツ クラブや民間スポーツクラブ）への移行および連 携についても同様である。そのため，あくまでも 小学校部活動のスポーツ少年団への完全移行によ って起こる可能性があることという理解にとどめ たい. また，教員の視点のみからの調査であるた め, 子どもや保護者に関する変化は, 当事者の認 識する主観的な変化ではなく, 教員が認識してい る変化である点には留意しなければならない。 ス ポーツ政策や教育政策へと活かしていくために
は，どの程度の教員がどのような変化を認識して いるかを定量的に示すことなどを通して，実態を 明確に理解していくことが必要である. 本研究は 小学校部活動のスポーツ少年団への移行を対象と した一事例であるが，これまで主題としてあまり 扱われてこなかった部活動の地域移行によって生 じうる変化を示唆し, 今後, 中学校や高等学校を 含めた持続可能な部活動やスポーツ環境の在り方 を検討する際に考慮すべき視点を提供しうると考 えられる。

\section{謝辞}

本研究は JSPS 科研費 JP16K16535, JP19K20053 の助成を受けたものです.

\section{注}

1）論文掲載当時は教員でなければ部活動顧問になるこ とはできなかったが，2017 年 4 月に学校教育法施行 規則が改正され, 「部活動指導員」という立場が設け られた.これにより, 部活動指導員は学校職員として 部活動の顧問を担当することが可能になった.

2）統計には部活動のある小学校と部活動のない小学校 が無作為に含まれているため, 全国的に実施されてい るわけではない小学校部活動の実態が明快に反映され ている時間ではない.

\section{文 献}

天草市（2016）小学校運動部活動の社会体育移行に向 けて. 市政だより, 250: 2-3. https://www.city.amakusa. kumamoto.jp/kiji0032377/3_2377_460_up_tu8bs5pe.pdf (参照日 2020 年 5 月 6 日)

青柳健隆（2019a）運動部顧問教員のワークライフバラ ンスに関連する要因. 関東学院大学経済経営研究所年 報, $41: 10-16$.

青柳健隆(2019b)部活動の指導とワークライフバランス. 青柳健隆・岡部祐介編, 部活動の論点「これからを 考えるためのヒント」. 旬報社. pp.144-145.

青柳健隆・鈴木郁弥・荒井弘和・岡浩一朗（2018）小学 校に打ける運動部活動の分布：市区町村別実施状況マ ップの作成. スポーツ産業学研究, 28(3) : 265-273.

朝日新聞（2018 年 9 月 23 日）別の放課後活動「必要」 6 割 小学校部活, 名古屋市民アンケ.

朝日新聞（2020 年 4 月 23 日）五輪をめぐる スポーツ 少年団：3 増える選択肢 生き残る道は.

東愛知新聞 (2019 年 7 月 10 日) 豊橋の小学校 運 
動部活動廃止 . http://www.higashiaichi.co.jp/news/ detail/4935（参照日 2020 年 5 月 6 日）

石井十郎・浪越一喜・川邊保孝（2016）運動部活動の場 としての総合型地域スポーツクラブの可能性. 帝京大 学スポーツ医療研究, $8:$ 17-24.

川喜田二郎（1970）続・発想法：KJ 法の展開と応用. 中央公論新社.

国立教育政策研究所編（2019）教員環境の国際比較 OECD 国際教員指導環境調査（TALIS）2018 報告書一 学び続ける教員と校長. ぎょうせい. p.13.

熊本県阿蘇市（2018）平成 31 年 3 月末までに小学校運 動部活動は廃止されます。広報あそ2018 年 3 月号. http://www.city.aso.kumamoto.jp/files/uploads/2018/02/ pr201803_8-11.pdf（参照日 2020 年 5 月 6 日）

熊本市教育委員会（2017）熊本市立小・中学校の運動 部活動について〈指針〉. https://www.city.kumamoto. jp/common/UploadFileDsp.aspx?c_id=5\&id=15527\&sub_ $\mathrm{id}=1 \&$ flid $=103223$ （参照日 2020 年 5 月 6 日）

黒須充編（2009）総合型地域スポーツクラブの時代 部 活とクラブとの協働. 創文企画.

京都市立小学校運動部活動の在り方に関する検討委員会 （2017）京都市立小学校運動部活動等ガイドライン. https://www.city.kyoto.lg.jp/kyoiku/cmsfiles/contents/00002 03/203422/29syougaidorain.pdf(参照日 2020 年 5 月 6 日) 松本典子（2019）幼児の運動活動の場としてのスポーツ 少年団. 鳥取看護大学・鳥取短期大学研究紀要, 79 : 19-27.

益城町（2018）小学校運動部活動の運営方法が変更にな ります (平成 31 年 4 月〜). https://www.town.mashiki. lg.jp/kiji0032241/index.html（参照日 2020 年 5 月 6 日） 文部科学省 (2019) 文部科学統計要覧 (平成 31 年版). https://www.mext.go.jp/b_menu/toukei/002/002b/1417059. $\mathrm{htm}$ (参照日 2020 年 5 月 6 日)

永谷稔（2015）学校運動部活動と総合型地域スポーツク ラブの連携について：都市と地方都市クラブにおける 事例比較. 北翔大学生涯スポーツ学部研究紀要, 6: 29-36.

名古屋市教育委員会（online）部活動. http://www.city. nagoya.jp/kyoiku/page/0000051145.html（参照日 2020 年 5 月 6 日）

中澤篤史（2008）運動部活動改革への保護者のかかわり に関する社会学的考察：公立中学校サッカー部の事例 研究. スポーツ科学研究, 5:79-95.

中澤篤史（2014）運動部活動の戦後と現在 なぜスポー ツは学校教育に結び付けられるのか. 青弓社. pp.119120.

中澤篤史（2017）そろそろ, 部活のこれからを話しませ んか:未来のための部活講義. 大月書店.

成田市教育委員会 (2018) 成田市部活動経営ガイドラ
イン. https://www.city.narita.chiba.jp/content/000073842. pdf（参照日 2020 年 5 月 6 日）

夏秋英房（2003）愛知県半田市の総合型地域スポーツク ラブの展開と運動部活動. 聖徳大学生涯学習研究所紀 要 生涯学習研究, 1:15-24.

日本スポーツ協会（2019）令和元年度都道府県別団数・ 団員数・指導者数一覧. https://www.japan-sports.or.jp/ Portals/0/R1_zenbusyuukei.pdf(参照日 2020 年 5 月 6 日) 日本スポーツ協会日本スポーツ少年団（2018）ガイドブ ック「スポーツ少年団とは」.日本スポーツ協会日本 スポーツ少年団.

日本スポーツ協会総合企画委員会（2018）提言「今度 の地域スポーツ体制の在り方についてージュニア スポーツを中心としてー」. https://www.japan-sports. or.jp/Portals/0/data0/about/pdf/20180606_Regarding_the future_of_the_regional_sports_system.pdf（参照日 2020 年 5 月 6 日)

西原村（online）小学校部活動の社会体育移行に伴うス ポーツ指導サポーターの募集について. http://www. vill.nishihara.kumamoto.jp/education_committee/society_ sports/2793.html（参照日 2020 年 5 月 6 日）

大杉成喜・今田直人（2016）特別な配慮を要する览童の 運動部活動参加についての研究：熊本県内小学校運動 部活動の社会体育移行を見据えて．熊本大学教育学部 紀要, $65: 131-138$.

大竹弘和・上田幸夫（2001）地域スポーツとの「融合」 を通した学校運動部活動の再構成. 日本体育大学紀要, 30(2) : 269-277.

笹川スポーツ財団（2017a）子ども・青少年のスポーツ ライフ・データ 2017. 笹川スポーツ財団.

笹川スポーツ財団（2017b） スポーツ白書 2017 スポー ツによるソーシャルイノベーション. 笹川スポーツ財 団.

スポーツ庁 (2018a) 平成 29 年度 運動部活動等に関す る実態調查報告書. 東京書籍.

スポーツ庁（2018b）運動部活動の在り方に関する 総合的なガイドライン. https://www.mext.go.jp/ sports/b_menu/shingi/013_index/toushin/_icsFiles/ afieldfile/2018/03/19/1402624_1.pdf（参照日 2020 年 5 月 6 日)

高村梨江・高橋豪仁（2006）学校運動部と地域スポーツ クラブとの融合：ソレステレージャ奈良 2002 を事例 にして．奈良教育大学紀要, 55(1)：165-176.

谷口勇一（2014）部活動と総合型地域スポーツクラブ の関係構築動向をめぐる批判的検討 :「失敗事例」か らみえてきた教員文化の諸相をもとに。体育学研究, $59: 559-576$.

谷口勇一（2018）地方自治体スポーツ行政は部活動改革 動向とどう向かい合っているのか：総合型クラブ育成 
を担当した元指導主事の意識から見えてきた行政文化 の諸相. 体育学研究, $63: 853-870$.

内田良（2017）ブラック部活動：子どもと先生の苦しみ

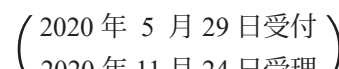
に向き合う. 東洋館出版社.

依田充代・森川貞夫・海老原修（1997）運動部活動の 地方移行に関する研究：「スポーツの主人公にふさわ 2020 年 11 月 24 日受理 しい能力」からの分析・検討. 日本体育大学紀要, Advance Publication by J-STAGE Published online 2020/12/5 $27(1): 25-44$. 